\title{
Regional Young Child Poverty in 2008: Rural Midwest Sees Increased Poverty, While Urban Northeast Rates Decrease
}

A merican Community Survey (ACS) data released by the U.S. Census Bureau on September 29, 2009, reveal interesting trends in poverty for young children-under the age of 6 . For those young children living in the rural Midwest, poverty rates increased by 1.7 percent over the past year, while rates for young children in the urban Northeast dropped by 0.7 percentage point. Also striking is the very high rate of young child poverty experienced by those in the South: Nearly one-third of young children in the rural South are poor.

Although all children suffer consequences of being poor, young children are especially vulnerable. Women in poverty are more likely to have babies of low birth weight, a correlate of later health problems, infant mortality, and more cognitive and emotional problems. ${ }^{1}$ Other challenges include poorer health, lower quality education and programs, lower cognitive and behavioral functioning, and greater parental stress. There is also evidence that poverty is associated with a lower quality home environment and less effective parenting practices. ${ }^{2}$ Being poor also means that families may have trouble accessing adequate quality food and young children may experience stunted growth. Poor children live in lowerquality housing. In many communities, this means young children are exposed to lead paint. Prenatal exposure and exposure at young ages through inhalation and ingestion of paint chips can lead to a variety of health problems and decreased intelligence. The consequences of early poverty ripple through the life cycle for many children. Childhood health problems often follow into adulthood, and early childhood poverty is correlated with fewer years of completed schooling. ${ }^{3}$

While changes from 2007 through 2008 are important, they cannot fully reflect the current recession. ACS data are collected throughout the calendar year, so the 2008 data reflect January through December 2008. When data are available for 2009, we are likely to see a bleaker picture for poverty and for children in particular. Consensus among experts is that 2008 does not capture the worst effects of the

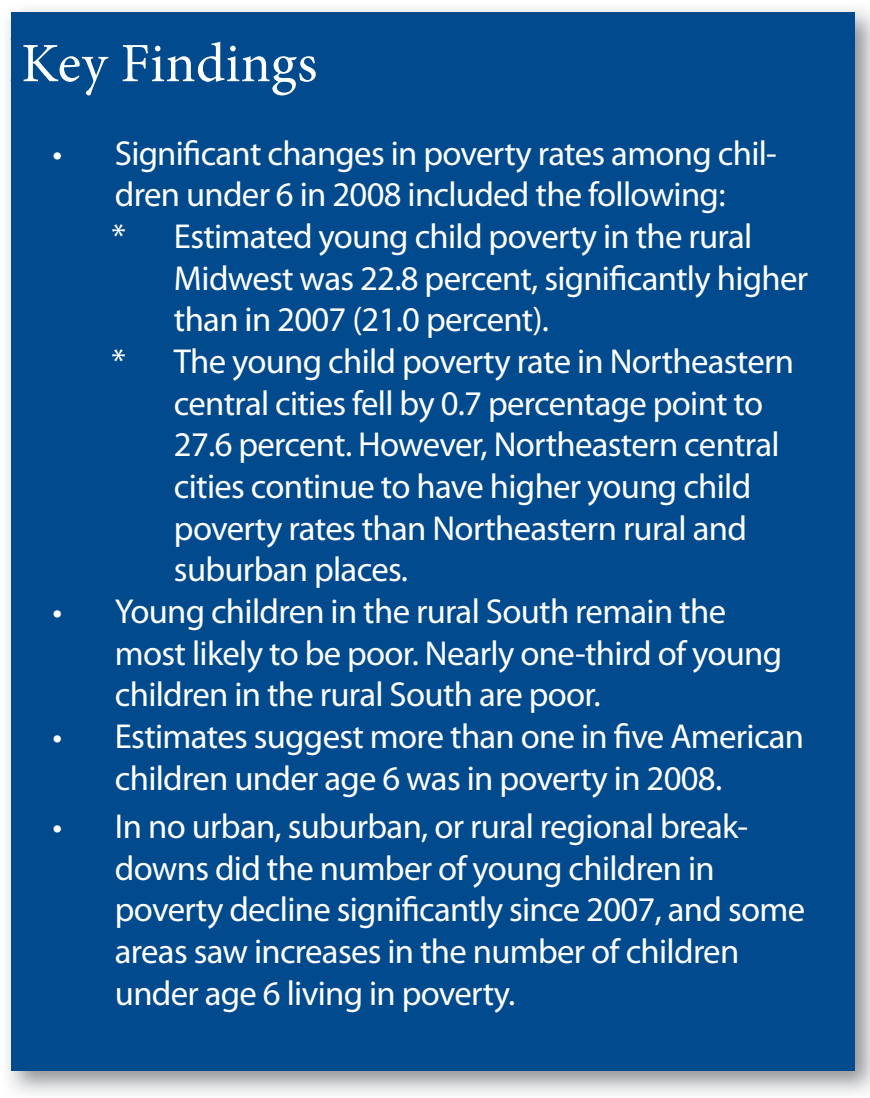

recession. ${ }^{4}$ As Robert Greenstein of the Center for Budget and Policy Priorities noted, a further weakened economy coupled with higher unemployment in 2009 may lead to the highest poverty rate in 50 years. ${ }^{5}$ Emily Monea and Isabel Sawhill predicted future poverty rates given the economic climate and found a bleak picture for America's children, suggesting that by 2011, between 5.4 and 6.1 million more children will be living in poverty without dramatic changes. ${ }^{6}$

Table 1 is restricted to very young children and shows 2008 estimates of those in poverty, poverty rates, and the change in poverty rates since 2007 by region and for the United States. Poverty determination is based on the U.S. 
TABLE 1. YOUNG CHILD POVERTY BY PLACE SIZE IN 2008

\begin{tabular}{|c|c|c|c|c|c|c|c|c|c|c|c|c|}
\hline & \multicolumn{12}{|c|}{2008 AMERICAN COMMUNITY SURVEY } \\
\hline & \multicolumn{4}{|c|}{ RURAL } & \multicolumn{4}{|c|}{ SUBURBAN } & \multicolumn{4}{|c|}{ CENTRAL CITY } \\
\hline & $\begin{array}{c}\text { POPULATION UNDER } \\
\text { AGE } 6 \text { FOR WHOM } \\
\text { POVERTY IS DETER- } \\
\text { MINED }\end{array}$ & $\begin{array}{l}\text { BELOW } \\
\text { POVERTY }\end{array}$ & $\begin{array}{l}\text { PERCENT } \\
\text { BELOW } \\
\text { POVERTY }\end{array}$ & $\begin{array}{c}\text { Percent } \\
\text { PoINT } \\
\text { ChANGE } \\
\text { SinCE } 2007\end{array}$ & $\begin{array}{c}\text { POPULATION UNDER } \\
\text { AGE } 6 \text { FOR WHOM } \\
\text { POVERTY IS DETER- } \\
\text { MINED }\end{array}$ & $\begin{array}{l}\text { BELOW } \\
\text { POVERTY }\end{array}$ & $\begin{array}{l}\text { PERCENT } \\
\text { BELOW } \\
\text { POVERTY }\end{array}$ & $\begin{array}{l}\text { PERCENT } \\
\text { PoInt } \\
\text { ChANGE } \\
\text { Since }\end{array}$ & $\begin{array}{c}\text { POPULATION UNDER } \\
\text { AGE } 6 \text { FOR WHOM } \\
\text { POVERTY IS DETER- } \\
\text { MINED }\end{array}$ & $\begin{array}{l}\text { BELOW } \\
\text { POVERTY }\end{array}$ & $\begin{array}{l}\text { PERCENT } \\
\text { BELOW } \\
\text { POVERTY }\end{array}$ & $\begin{array}{c}\text { PERCENT } \\
\text { PoInt } \\
\text { CHANGE } \\
\text { Since }\end{array}$ \\
\hline UnIted StATES & $3,660,889$ & 970,407 & $26.5 \%$ & $0.8 \%$ & $12,383,825$ & $1,906,933$ & $15.4 \%$ & $0.6 \%$ & $8,431,955$ & $2,240,857$ & $26.6 \%$ & $-0.2 \%$ \\
\hline NoRTHEAST & 330,783 & 68,788 & $20.8 \%$ & $1.9 \%$ & $2,289,294$ & 256,293 & $11.2 \%$ & $0.7 \%$ & $1,308,055$ & 360,560 & $27.6 \%$ & $-2.4 \%$ \\
\hline MIDWEST & $1,117,265$ & 254,505 & $22.8 \%$ & $1.7 \%$ & $2,543,142$ & 341,095 & $13.4 \%$ & $0.5 \%$ & $1,558,611$ & 450,533 & $28.9 \%$ & $0.3 \%$ \\
\hline SOUTH & $1,679,310$ & 523,601 & $31.2 \%$ & $0.1 \%$ & $4,628,916$ & 825,360 & $17.8 \%$ & $0.4 \%$ & $2,947,165$ & 855,078 & $29.0 \%$ & $-0.4 \%$ \\
\hline WEST & 533,531 & 123,513 & $23.2 \%$ & $0.4 \%$ & $2,922,473$ & 484,185 & $16.6 \%$ & $0.9 \%$ & $2,618,124$ & 574,686 & $22.0 \%$ & $0.7 \%$ \\
\hline
\end{tabular}

'Levels of urbanization are defined as follows: rural consists of ACS geographic components "Not in metropolitan or micropolitan statistical area" and "in micropolitan statistical area"; suburban includes "In metropolitan statistical area - not in principal city" and central city includes "In metropolitan statistical area - in principal city".

${ }^{2}$ Data are based on 2008 American Community Survey estimates. For corresponding margins of error, refer to the US Census American Community Survey.

Office of Management and Budget income thresholds, which vary by family composition. In 2008, the poverty line for a family of four (two adults, two children) was $\$ 21,834$.

Observed differences are likely driven by a host of factors not captured here. These include the demographics of the population (race, single motherhood, parental education and employment, and so on) and local characteristics, including access to services, housing quality, social capital, and job market conditions.

Data released earlier this month by the Census Bureau showed that while young children remain the most likely to be in poverty, this group did not see overall increases in the national poverty rate at 21.3 percent in $2008 .^{7}$ However, the Census Bureau's own report indicates that the overall U.S. poverty rate jumped significantly from 2007, and more people in the United States are living in poverty than in any year since $1960 .^{8}$ The Census report indicates that children have been especially hard hit by this recession: The poverty rate for all children under age 18 reached 19 percent in 2008, up from 18 percent a year earlier. Of all ages, children remain the group most likely to be poor. ${ }^{9}$ According to the Census report, they represent 24.6 percent of the population but 35.3 percent of those in poverty.

The ACS data allow examination of the poverty rate by state and place.

Table 2 shows estimated child poverty - under age 18-numbers and rates for each state, each region, and the nation, by place. Rates by state and place are presented for illustrative purposes to guide comparisons, but in most cases, differences since 2007 are not statistically significant.

Persistent child poverty indicates a need for policies that focus on children, particularly in the early years. In this "great recession," while it may be tempting to cut services to children and families, this is a time when policies need to target these groups and do a better job of assisting those who are in poverty. Additionally, since this recession is not over, and we have seen dramatic declines in income, many families above the poverty line may need additional support to remain afloat. Investing in children is an essential priority to ensure their successful long-term outcomes. Expanding the provisions provided for in the American Recovery and Reinvestment Act may be an important first step, but other measures to address child poverty and focus on poverty reduction are also important. While President Barack Obama's administration has taken important steps to assist struggling families, there is still important work to be done at both the federal and state levels. Keeping poverty reduction as a top policy priority will enhance the well-being of America's children.

\section{Data}

This analysis is based upon U.S. Census Bureau estimates from the 2008 ACS released on September 29, 2009. For more details or information, please refer to the U.S. Census American Community Survey. ${ }^{10}$ Tables were produced by aggregating information from detailed tables available on American FactFinder (http://factfinder.census.gov/home/ saff/main.html?_lang=en). These estimates are meant to give perspective on child poverty, but since they are based on survey data, caution must be used in comparing across years or places, as the margin of error may indicate that seemingly disparate numbers fall within sampling error. ${ }^{11}$ Regional differences highlighted in this brief are statistically significant $(\mathrm{p}<0.05)$.

\section{ENDNOTES}

1. Brooks-Gunn, Jeanne, and Greg. J. Duncan. 1997. “The effects of poverty on children." The Future Of Children / Center For The Future Of Children, The David And Lucile Packard Foundation 7:55-71.

2. See Bradley, Robert H., Corwyn, Robert F., McAdoo, H. P., \& García Coll, C. G. (2001). The home environments of children in the United States part I: Variations by age, ethnicity, and poverty status. Child Development, 72, 1844-1886.

3. See Case, Anne, Angela Fertig, and Christina Paxson. 2005. "The lasting impact of childhood health and cir- 
TABLE 2. CHILD POVERTY BY PLACE SIZE IN 2008

\begin{tabular}{|c|c|c|c|c|c|c|c|c|c|c|c|c|}
\hline & \multicolumn{12}{|c|}{2008 AMERICAN COMMUNITY SURVEY } \\
\hline & \multicolumn{4}{|c|}{ RURAL } & \multicolumn{4}{|c|}{ SUBURBAN } & \multicolumn{4}{|c|}{ CENTRAL CITY } \\
\hline & $\begin{array}{c}\text { POPULATION UNDER } \\
\text { AGE } 18 \text { FOR } \\
\text { WHOM POVERTY IS } \\
\text { DETERMINED }\end{array}$ & $\begin{array}{l}\text { BELOW } \\
\text { POVERTY }\end{array}$ & $\begin{array}{c}\text { PERCENT } \\
\text { BELOW } \\
\text { POVERTY }\end{array}$ & $\begin{array}{c}\text { PERCENT } \\
\text { PoINT } \\
\text { CHANGE } \\
\text { SINCE } 2007\end{array}$ & $\begin{array}{c}\text { POPULATION UNDER } \\
\text { AGE } 18 \text { FOR } \\
\text { WHOM POVERTY IS } \\
\text { DETERMINED }\end{array}$ & $\begin{array}{l}\text { BELOW } \\
\text { POVERTY }\end{array}$ & $\begin{array}{l}\text { PERCENT } \\
\text { BELOW } \\
\text { POVERTY }\end{array}$ & $\begin{array}{c}\text { PERCENT } \\
\text { PoINT } \\
\text { CHANGE } \\
\text { SINCE 2007 }\end{array}$ & $\begin{array}{c}\text { POPULATION UNDER } \\
\text { AGE } 18 \text { FOR } \\
\text { WHOM POVERTY IS } \\
\text { DETERMINED }\end{array}$ & $\begin{array}{l}\text { BELOW } \\
\text { POVERTY }\end{array}$ & $\begin{array}{l}\text { PERCENT } \\
\text { BELOW } \\
\text { POVERTY }\end{array}$ & $\begin{array}{c}\text { PERCENT } \\
\text { PoINT } \\
\text { CHANGE } \\
\text { SINCE } 2007\end{array}$ \\
\hline United States & $11,187,926$ & $2,499,004$ & $22.3 \%$ & 0.4 & $38,282,003$ & $5,047,946$ & $13.2 \%$ & 0.3 & $23,355,074$ & $5,693,920$ & $24.4 \%$ & -0.3 \\
\hline$\overline{\text { Alabama }}$ & 307,572 & 81,031 & $26.3 \%$ & -1.0 & 515,688 & 79,456 & $15.4 \%$ & -5.0 & 282,753 & 80,031 & $28.3 \%$ & 0.0 \\
\hline ALASKA & 43,745 & 7,472 & $17.1 \%$ & -2.5 & 41,564 & 3,592 & $8.6 \%$ & -0.3 & 78,964 & 7,203 & $9.1 \%$ & -0.3 \\
\hline ARIZONA & 125,261 & 34,995 & $27.9 \%$ & -3.1 & 727,078 & 117,107 & $16.1 \%$ & 0.4 & 828,202 & 197,288 & $23.8 \%$ & 1.5 \\
\hline ARKANSAS & 262,216 & 71,343 & $27.2 \%$ & -1.7 & 228,908 & 42,992 & $18.8 \%$ & -2.2 & 200,201 & 57,514 & $28.7 \%$ & 1.6 \\
\hline CALIFORNIA & 162,179 & 35,297 & $21.8 \%$ & 3.3 & $4,732,249$ & 776,814 & $16.4 \%$ & 1.2 & $4,323,520$ & 888,799 & $20.6 \%$ & 1.1 \\
\hline Colorado & 149,192 & 20,099 & $13.5 \%$ & -5.3 & 605,684 & 64,171 & $10.6 \%$ & -0.7 & 436,060 & 95,139 & $21.8 \%$ & -0.8 \\
\hline Connecticut & 64,771 & 6,872 & $10.6 \%$ & 3.1 & 514,107 & 41,735 & $8.1 \%$ & 0.5 & 220,420 & 50,973 & $23.1 \%$ & 2.8 \\
\hline Delaware & 39,808 & 8,085 & $20.3 \%$ & 6.7 & 141,415 & 14,804 & $10.5 \%$ & -1.0 & 23,213 & 4,844 & $20.9 \%$ & -14.6 \\
\hline FLORIDA & 205,079 & 56,796 & $27.7 \%$ & 6.2 & $2,743,782$ & 461,457 & $16.8 \%$ & 1.7 & 992,771 & 203,031 & $20.5 \%$ & -0.9 \\
\hline GEORGIA & 434,306 & 116,778 & $26.9 \%$ & 1.0 & $1,676,873$ & 266,455 & $15.9 \%$ & 0.9 & 390,572 & 118,659 & $30.4 \%$ & -2.2 \\
\hline Hawall & 84,801 & 9,253 & $10.9 \%$ & -0.4 & 133,936 & 11,809 & $8.8 \%$ & -1.2 & 62,229 & 7,171 & $11.5 \%$ & 4.4 \\
\hline IDAHO & 137,479 & 28,328 & $20.6 \%$ & 2.9 & 149,478 & 17,837 & $11.9 \%$ & -1.3 & 120,610 & 18,308 & $15.2 \%$ & -2.0 \\
\hline ILLINOIS & 346,926 & 67,420 & $19.4 \%$ & 2.0 & $1,741,520$ & 199,108 & $11.4 \%$ & 0.5 & $1,052,502$ & 268,669 & $25.5 \%$ & -0.2 \\
\hline INDIANA & 330,259 & 64,768 & $19.6 \%$ & 1.7 & 730,229 & 92,452 & $12.7 \%$ & 1.1 & 488,936 & 126,007 & $25.8 \%$ & 0.5 \\
\hline IowA & 291,163 & 47,144 & $16.2 \%$ & 1.5 & 204,543 & 15,499 & $7.6 \%$ & 1.3 & 202,484 & 38,042 & $18.8 \%$ & -0.5 \\
\hline KansAS & 236,774 & 40,036 & $16.9 \%$ & 0.0 & 228,799 & 17,367 & $7.6 \%$ & -1.3 & 221,660 & 42,369 & $19.1 \%$ & 0.8 \\
\hline KENTUCKY & 401,161 & 115,910 & $28.9 \%$ & -0.4 & 358,883 & 59,980 & $16.7 \%$ & -0.6 & 231,155 & 56,810 & $24.6 \%$ & 0.0 \\
\hline LoUISIANA & 287,728 & 82,945 & $28.8 \%$ & -5.0 & 491,824 & 85,762 & $17.4 \%$ & -2.2 & 315,015 & 102,087 & $32.4 \%$ & 0.9 \\
\hline MAINE & 105,542 & 18,597 & $17.6 \%$ & -0.8 & 124,397 & 13,645 & $11.0 \%$ & -1.0 & 37,355 & 9,989 & $26.7 \%$ & 8.6 \\
\hline MARYLAND & 65,853 & 8,942 & $13.6 \%$ & 2.6 & $1,031,077$ & 82,632 & $8.0 \%$ & 0.1 & 226,042 & 43,316 & $19.2 \%$ & -2.4 \\
\hline MaSSACHUSETTS & $\mathrm{N} / \mathrm{A}$ & $\mathrm{N} / \mathrm{A}$ & N/A & N/A & $1,084,594$ & 95,810 & $8.8 \%$ & -0.2 & 322,415 & 73,624 & $22.8 \%$ & -3.1 \\
\hline MICHIGAN & 392,259 & 79,429 & $20.2 \%$ & 0.6 & $1,329,292$ & 172,029 & $12.9 \%$ & 0.4 & 636,534 & 206,845 & $32.5 \%$ & -0.9 \\
\hline MINNESOTA & 304,831 & 41,982 & $13.8 \%$ & 0.4 & 661,003 & 48,786 & $7.4 \%$ & -1.0 & 267,313 & 49,443 & $18.5 \%$ & -1.2 \\
\hline MISSISSIPPI & 411,794 & 144,028 & $35.0 \%$ & -0.2 & 251,624 & 53,082 & $21.1 \%$ & 4.1 & 88,472 & 31,462 & $35.6 \%$ & -0.4 \\
\hline MIssourI & 354,436 & 86,547 & $24.4 \%$ & 2.9 & 756,902 & 94,283 & $12.5 \%$ & -0.2 & 281,072 & 78,187 & $27.8 \%$ & 1.8 \\
\hline Montana & 140,873 & 31,154 & $22.1 \%$ & 1.7 & 28,464 & 4,031 & $14.2 \%$ & 2.7 & 49,262 & 9,873 & $20.0 \%$ & 3.0 \\
\hline NEBRASKA & 167,730 & 23,117 & $13.8 \%$ & -2.3 & 112,431 & 9,788 & $8.7 \%$ & 0.6 & 155,265 & 25,449 & $16.4 \%$ & -2.3 \\
\hline NeVADA & 45,824 & 5,736 & $12.5 \%$ & -1.4 & 318,991 & 43,090 & $13.5 \%$ & 0.5 & 279,661 & 47,763 & $17.1 \%$ & -0.4 \\
\hline New HampSHIRE & 88,884 & 11,439 & $12.9 \%$ & 4.0 & 146,910 & 6,069 & $4.1 \%$ & -1.2 & 43,967 & 7,558 & $17.2 \%$ & -0.4 \\
\hline NEW JERSEY & N/A & $N / A$ & N/A & N/A & $1,798,186$ & 187,912 & $10.5 \%$ & 0.9 & 228,359 & 65,466 & $28.7 \%$ & -0.7 \\
\hline New Mexico & 168,678 & 46,731 & $27.7 \%$ & -0.1 & 151,430 & 33,873 & $22.4 \%$ & -3.2 & 172,595 & 38,412 & $22.3 \%$ & -0.7 \\
\hline NEW YoRK & 313,193 & 64,014 & $20.4 \%$ & 1.0 & $1,854,076$ & 168,511 & $9.1 \%$ & 0.5 & $2,178,095$ & 596,815 & $27.4 \%$ & -1.2 \\
\hline NoRth CAROLINA & 627,103 & 157,597 & $25.1 \%$ & 0.8 & 913,460 & 141,303 & $15.5 \%$ & 1.4 & 669,466 & 140,618 & $21.0 \%$ & -1.2 \\
\hline NORTH DAKOTA & 70,587 & 11,413 & $16.2 \%$ & 0.9 & 28,862 & 3,706 & $12.8 \%$ & 4.9 & 39,785 & 6,147 & $15.5 \%$ & 1.6 \\
\hline Оноо & 515,115 & 101,027 & $19.6 \%$ & 1.0 & $1,548,750$ & 179,136 & $11.6 \%$ & -0.6 & 628,500 & 218,224 & $34.7 \%$ & 0.2 \\
\hline OKLаноMA & 305,323 & 80,371 & $26.3 \%$ & 1.1 & 325,178 & 50,726 & $15.6 \%$ & 0.1 & 257,216 & 69,324 & $27.0 \%$ & -1.0 \\
\hline OREGon & 180,444 & 39,785 & $22.0 \%$ & 0.9 & 389,716 & 60,861 & $15.6 \%$ & 1.3 & 282,299 & 53,552 & $19.0 \%$ & 1.1 \\
\hline Pennsylvania & 404,659 & 65,009 & $16.1 \%$ & -0.8 & $1,719,227$ & 191,394 & $11.1 \%$ & 1.1 & 593,247 & 190,032 & $32.0 \%$ & -2.6 \\
\hline RHODE IsLAND & N/A & $N / A$ & N/A & N/A & 152,475 & 18,937 & $12.4 \%$ & -0.5 & 72,448 & 15,879 & $21.9 \%$ & -4.5 \\
\hline SOUth Carolina & 246,379 & 65,009 & $26.4 \%$ & 0.3 & 650,684 & 120,946 & $18.6 \%$ & 0.7 & 155,066 & 41,913 & $27.0 \%$ & 1.1 \\
\hline SOUTH DAKOTA & 101,270 & 21,543 & $21.3 \%$ & 0.0 & 42,635 & 3,530 & $8.3 \%$ & 2.3 & 49,346 & 8,903 & $18.0 \%$ & 2.1 \\
\hline Tennessee & 366,312 & 90,898 & $24.8 \%$ & -1.6 & 584,440 & 74,914 & $12.8 \%$ & -2.2 & 503,252 & 150,664 & $29.9 \%$ & -0.0 \\
\hline TEXAS & 718,738 & 187,423 & $26.1 \%$ & -0.6 & $2,885,609$ & 481,416 & $16.7 \%$ & -0.5 & $3,046,302$ & 828,964 & $27.2 \%$ & -0.8 \\
\hline UтАн & 87,199 & 12,266 & $14.1 \%$ & -3.2 & 590,311 & 49,751 & $8.4 \%$ & 0.4 & 164,576 & 26,432 & $16.1 \%$ & -2.0 \\
\hline VERMONT & 80,730 & 11,324 & $14.0 \%$ & -0.9 & 36,411 & 3,292 & $9.0 \%$ & 2.2 & $N / A$ & $N / A$ & $N / A$ & N/A \\
\hline VIRGINIA & 220,607 & 48,903 & $22.2 \%$ & 2.8 & $1,095,826$ & 100,884 & $9.2 \%$ & 0.3 & 475,934 & 96,947 & $20.4 \%$ & 0.8 \\
\hline WASHINGTON & 173,787 & 35,068 & $20.2 \%$ & 0.1 & 915,339 & 105,297 & $11.5 \%$ & -0.8 & 429,179 & 76,637 & $17.9 \%$ & -0.9 \\
\hline WEST VIRGINIA & 166,932 & 44,101 & $26.4 \%$ & 0.1 & 167,340 & 29,841 & $17.8 \%$ & -0.2 & 44,062 & 13,046 & $29.6 \%$ & 1.0 \\
\hline WISCONSIN & 324,710 & 48,415 & $14.9 \%$ & 0.6 & 606,342 & 47,681 & $7.9 \%$ & -0.2 & 362,103 & 76,084 & $21.0 \%$ & -3.9 \\
\hline WYoming & 86,625 & 9,196 & $10.6 \%$ & -3.1 & $\mathrm{~N} / \mathrm{A}$ & N/A & N/A & N/A & 25,788 & 3,013 & $11.7 \%$ & 4.7 \\
\hline NORTHEAST & $1,071,729$ & 187,146 & $17.5 \%$ & 1.1 & $7,430,383$ & 727,305 & $9.8 \%$ & 0.6 & $3,705,599$ & $1,012,366$ & $27.3 \%$ & -1.3 \\
\hline MIDWEST & $3,436,060$ & 632,841 & $18.4 \%$ & 1.0 & $7,991,308$ & 883,365 & $11.1 \%$ & 0.1 & $4,385,500$ & $1,144,369$ & $26.1 \%$ & -0.4 \\
\hline SOUth & $5,066,911$ & $1,360,160$ & $26.8 \%$ & 0 & $14,062,611$ & $2,146,650$ & $15.3 \%$ & 0.2 & $8,011,030$ & $2,067,595$ & $25.8 \%$ & -0.6 \\
\hline WEST & $1,613,226$ & 318,857 & $19.8 \%$ & -0.4 & $8,797,701$ & $1,290,626$ & $14.7 \%$ & 0.6 & $7,252,945$ & $1,469,590$ & $20.3 \%$ & 0.7 \\
\hline
\end{tabular}

$\mathrm{N} / \mathrm{A}=$ Not applicable.

"Levels of urbanization are defined as follows: rural consists of ACS geographic components "Not in metropolitan or micropolitan statistical area" and "in micropolitan statistical area"; suburban includes "In metropolitan statistical area - not in principal city" and central city includes "In metropolitan statistical area - in principal city"

2Data are based on 2008 American Community Survey estimates. For corresponding margins of error, refer to the US Census American Community Survey.

${ }^{3}$ Percentage point changes are based on unrounded poverty percentages and may differ slightly from those that would be obtained using rounded figures. 
cumstance." Journal of Health Economics 24:365-389, who examined the impact of prenatal conditions and child health at age 7 on various outcomes and McLoyd, Vonnie. C. (1998). Socioeconomic disadvantages and child development. American Psychologist, 53, 185-204.

4. See Burtless, Gary. September 10, 2009. "Prepared Remarks on the 2008 poverty statistics" (Brookings Institution). http://www.brookings.edu/events/2009/0910_poverty. aspx; Greenstein, Robert. September 10, 2009. "Greenstein Statement on Census' 2008 Health Insurance \& Poverty Data” http://www.cbpp.org/cms/index.cfm?fa=view\&id=2911; Monea, Emily and Isabel Sawhill. September 10, 2009. "Simulating the Effect of the "Great Recession' on Poverty" (Brookings Institution), http://www.brookings.edu/ papers/2009/0910_poverty_monea_sawhill.aspx; Parrott, Sharon. 2008. "Recession Could Cause Large Increases in Poverty and Push Millions into Deep Poverty." (Center on Budget and Policy Priorities), http://www.cbpp.org/files/1124-08pov.pdf.

5. Greenstein, Robert. September 10, 2009. "Greenstein Statement on Census' 2008 Health Insurance \& Poverty Data” http://www.cbpp.org/cms/index.cfm?fa=view\&id=2911. 6. Monea, Emily and Isabel Sawhill. September 10, 2009. "Simulating the Effect of the "Great Recession' on Poverty" (Brookings Institution), http://www.brookings. edu/papers/2009/0910_poverty_monea_sawhill.aspx; see also Parrott, Sharon. 2008. "Recession Could Cause Large Increases in Poverty and Push Millions into Deep Poverty." (Center on Budget and Policy Priorities), http://www.cbpp. org/files/11-24-08pov.pdf who estimates closer to 2.6 to 3.3 million additional children in poverty.

7. Higher poverty rates for young children result in large part because younger children typically having younger parents who often command lower wages: see McLoyd, Vonnie. C. (1998). Socioeconomic disadvantages and child development. American Psychologist, 53, 185-204.

8. U.S. Census Bureau. September, 2009 Income, Poverty, and Health Insurance Coverage. http://www.census.gov/ prod/2009pubs/p60-236.pdf and see U.S. Census Bureau. September 2009 Poverty: 2008 Highlights http://www.census. gov/hhes/www/poverty/poverty08/pov08hi.html. See also Burtless, Gary. September 29, 2009. "Prepared Remarks on the 2008 poverty statistics (Brookings Institution).http:// www.brookings.edu/events/2009/0910_poverty.aspx 9. Moses, Jay. September 10, 2009. "A Legacy of Poverty: New Census Numbers Fail to Reflect the Severity of Inherited Problems" (Center for American Progress), http:// www.americanprogress.org/issues/2009/09/poverty_obama_ era.html.

10. http://factfinder.census.gov/servlet/

DTGeoSearchByListServlet?ds_name=ACS_2007_3YR_ G00_\&_lang=en\&_ts $=268570514748$

11. Refer to the U.S. Census Bureau's published tables for detailed margins of error.

\section{ABOUT THE AUTHOR}

Beth Mattingly is a family demographer at the Carsey Institute and research assistant professor of sociology at the University of New Hampshire. (beth.mattingly@unh.edu)

\section{A C K N O W L E D G M E N T S}

The author thanks Catherine Seabury, Anne Shattuck, and Michelle Stransky, graduate students working at the Carsey Institute, for their assistance in preparing this brief; Sarah Savage, an assistant research scientist at the Institute for Behavioral Research, University of Georgia, for guidance accessing the data; and Mil Duncan, Kenneth Johnson, Terri Rippett, and Amy Sterndale at the Carsey Institute, for comments.

\section{A UNIVERSITY Ai of NEW HAMPSHIRE}

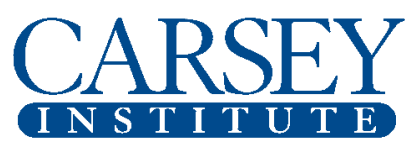

Building knowledge for families and communities

The Carsey Institute conducts policy research on vulnerable children, youth, and families and on sustainable community development. We give policy makers and practitioners timely, independent resources to effect change in their communities.

This work was supported by the Annie E. Casey Foundation, the W. K. Kellogg Foundation, and an anonymous donor.

Huddleston Hall

73 Main Street

Durham, NH 03824

(603) $862-2821$

www.carseyinstitute.unh.edu 